\title{
YANAGITA KUNIO (1875-1962). PIONIER JAPOŃSKICH BADAŃ FOLKLORYSTYCZNYCH
}

\begin{abstract}
Wstęp
Okres Meiji (1868-1912) pchnął Japonię w kierunku państwa nowoczesnego, zindustrializowanego oraz przede wszystkim pozytywistycznego. Era ta odgrywa istotną rolę w kształtowaniu się myśli etnograficznej (antropologicznej, folklorystycznej) w kraju. Jest to jednak tylko jedna strona medalu, który obok gigantycznego skoku cywilizacyjnego zawierał rewers - tradycyjny, swojski, by nie rzec ,japoński”. W latach 1868-1962 można wyróżnić dwa ważne okresy modernizacyjne w Japonii. Z kraju feudalnego rządzonego przez samurajów przekształciła się w kraj zdolny do konkurowania z wcześniej industrialnie rozwiniętymi potęgami kolonialnymi, zaś po II wojnie światowej, rezygnując z imperialnych ambicji, przekształciła się w państwo nowoczesne. W ciagu 100 lat nastąpiło wiele zmian na ulicach japońskiej stolicy. Można na nich było dostrzec dorożki, automobile, aby w końcu po 1945 r. móc obserwować latające nad głowami odrzutowce. Właśnie w takich czasach przyszło żyć i działać pionierowi japońskiej etnografii, folklorystyki czy też antropologii społeczno-kulturowej Yanagicie Kunio (1875-1962). Niniejszy tekst ma na celu zaprezentowanie sylwetki oraz głównych tez tego japońskiego badacza.
\end{abstract}

\section{Wczesne dzieciństwo}

Analizując wspomnienia twórcy japońskiej folklorystyki poświęcone rodzinnym stronom, widzimy obraz sielanki, zbliżony do wspomnień Bronisława Piłsudskiego na temat ojcowizny ${ }^{1}$. Ronald A. Morse w pracy poświęconej Yanagicie opisuje ziemie otaczające Tsujikawę - wieś rodzinną „ojca japońskiej folklorystyki” oraz jego wspomnienia z dzieciństwa:

Żyzna dolina usytuowana wzdłuż rzeki naznaczona zespołami domostw, których dachy pokryte były strzechą. Pola ryżowe rozciagające się aż po wzgórza, na których w cieniu

ORCID: 0000-0002-6780-5538, DOI: 10.4467/23538724GS.20.057.13497

1 Więcej na ten temat zob. J. Splisgart, Polski badacz. Ajnów - Bronisław Pitsudski (1866-1918). Wspomnienie w setna rocznice śmierci, „Gdańskie Studia Azji Wschodniej” 2018, z. 14, s. 112-127. 
drzew kryły się kapliczki i świątynie. Taki obraz japońskiej wsi najczęściej pielęgnował [w swoich pracach - J.S.] Yanagita. Właśnie tak wyglądała Tsujikawa, mała wieś w centralnej Japonii, gdzie urodził się Yanagita. Domy, pola ryżowe i mała, prawie rozpadająca się, świątynia na wzgórzu. Chram, Suzugamori, zacieniony przez ogromną śliwę był cichy i tajemniczy. Drzewo wyglądało jak bóstwo. Japońska religia ludowa z niezliczona ilością bóstw domowych, przydrożnych, świątynnych i górskich. Yanagita zapamiętał Suzugamori w połączeniu z okresem dzieciństwa. Kiedy rodziło się dziecko we wsi, matka przygotowywała specjalne danie ryżowe, które ofiarowywała bóstwu w zamian za opiekę. Dzieci, które uwielbiały potrawę, udawały się z matką do świątyni, aby w trakcie ceremonii spożyć przygotowane na tę szczególną okazję danie. Matka układała na dłoni każdego dziecka kęs potrawy i prosiła o bycie wyrozumiałym dla nowo narodzonego członka rodziny. Yanagita wspominał srogą reprymendę rodziców, gdy podczas ceremonii nie udało mu się utrzymać w dłoniach jedzenia. Lata później zaczął przykładać większą wagę do świątecznej natury świątyń sintoistycznych. Święta (festiwale) i ich społeczna rola, wszelkie oznaki i psychokulturowe wymiary wierzeń ludowych stały się centrum jego zainteresowań. Jeszcze później, gdy zaczął się mierzyć ze stratą [śmiercią - J.S.] rodziny i przyjaciół, zaczął koncentrować się na roli kultu przodków w życiu religijnym Japończyków. Na każdym etapie życia [Yanagity - J.S.], studiów folklorystycznych i prywatnych rozważań, wiejska świątynia stanowiła miejsce, w którym spotykały się razem historia i religia, [żyjąca - J.S.] społeczność i przodkowie, ludzie i bóstwa.

Tsujikawa ze swoim łagodnym, ale wilgotnym monsunowym klimatem jest położona na żyznych nizinach wzdłuż Morza Wewnętrznego. Niezbyt daleko od tradycyjnych stolic Japonii, składała się ze 120 domostw w 1880 r. i święciła najwspanialsze lata swojej świetności w okresie Tokugawa (1603-1868). Wspaniały zamek w położonym nieopodal mieście Himeji w prefekturze Hyōgo był administracyjnym i kulturowym centrum regionu. Wieś Tsujikawa położona była na skrzyżowaniu starej trasy Ikuno, którą przemierzali pielgrzymi do Ise oraz rzeki Ichi, głównej arterii transportowej pomiędzy górami a miastem Himeji².

To właśnie w takich warunkach 31 lipca 1875 r. w domu rodziny Matsuoka na świat przyszedł Kunio, w czasach gwałtownej transformacji politycznej, ustrojowej i społecznej. Nie sposób pominąć w tym miejscu postaci Fukuzawy Yukichiego (1835-1901), który, będąc gorącym orędownikiem zachodzących zmian, w swojej pracy Bunmeiron no gairyaku (S žkice o cywilizacji) tłumaczył Japończykom meandry cywilizacji zachodniej i przekonywał do przyjęcia nowych form kulturowo-społecznych. Kunio, pomimo że urodził się w wiejskim regionie, z dala od głównego nurtu przeobrażeń, nie uchronił się przed problemem „odcięcia” od tradycyjnych form kultury japońskiej i wystawienia na wpływy wkraczającej na wyspy nowoczesności ${ }^{3}$. Należy zauważyć, że o ile samej wsi Tsujikawy nie dotknęły bezpośrednio skutki przemian,

2 R.A. Morse, Yanagita Kunio and the folklore movement. The Search for Japan's National Character and Distictivness, New York - London 1990, s. 1-4.

3 Należy w tym miejscu zaznaczyć, że w przeciwieństwie do mieszkańców metropolii mieszkańcy wsi otoczeni byli kokonem, który chronił ich przed zbytnią ekspozycją na wpływy zewnętrzne (przynajmniej w początkowym okresie zmian). 
o tyle rodzinny dom Yanagity zaznał zawieruchy związanej zarówno z restauracją Meiji ${ }^{4}$, jak i problemami rodzinnymi. Ronald Morse wskazuje na dwa istotne powody takiego stanu rzeczy. Pierwszym z nich była generacyjna niestabilność rodu Matsuoka ${ }^{5}$ związana z licznymi rozwodami, które doprowadziły m.in. do tego, że ponad połowa mieszkańców wsi nosiła nazwisko Matsuoka. Drugi zaś to dzieje gałęzi rodu, z której wywodził się młody Kunio.

Protoplasta rodu - pradziadek Yù (1789-1840), który był niekwestionowanym lokalnym autorytetem w naukach konfucjańskich oraz chińskiej medycynie i zielarstwie $^{6}$, miał jedyną córkę Kozuru (? -1873). Babka Yanagity zaraz po ślubie i urodzeniu syna - Misao (1832-1896) opuściła męża i, odmawiając ponownego zamążpójścia, skupiła się na wychowaniu i edukacji potomka. Ze względu na zainteresowania literaturą klasyczną oraz wiedzę i umiejętności, jakie nabyła przy ojcu, pragnęła, aby jej syn odebrał właściwe wykształcenie w zakresie nauk i myśli konfucjańskiej oraz medycyny. Jednocześnie, nie zarzucając własnych pasji literaturoznawczych, zdecydowała się na otwarcie małej szkoły podstawowej dla dzieci sąsiadów (terakoya). Cechą charakterystyczną rodu Matsuoka był swoisty podział przebiegający na linii religijnej. O ile mężczyźni byli zdecydowanie związani z rodzimym shintō, o tyle kobiety przejawiały silne zaangażowanie w buddyzm ${ }^{7}$.

Młody Misao pod wpływem matki rozpoczął układanie poezji jako dziesięciolatek, zaś w wieku 13 lat rozpoczął studia nad myślą konfucjańską oraz medycyną chińska. Dzięki protektoratowi władz hanu Himeji ${ }^{8}$ Misao uzyskał dostęp do licznych prywatnych szkół regionalnych oraz oficjalnych placówek edukacyjnych opłacanych przez lokalnego feudała. Rok 1853 i ponowne wkroczenie na Wyspy Japońskie przedstawicieli Zachodu ${ }^{9}$ rozpaliły w młodym człowieku idee związane z okresem bakumatsu ${ }^{10}$, których myślą przewodnią była restauracja władzy cesarskiej oraz nacjonalizm silnie powiązany z sintoizmem. Pod wpływem nowych prądów myślowych przyłączył się do nastawionego nacjonalistycznie rodu kapłańskiego Hirata ${ }^{11}$.

4 Przywrócenie władzy cesarzowi i proklamowanie nowej ery w dziejach kraju.

5 R.A. Morse, Yanagita Kunio...

6 Ibidem.

7 Zarówno babka, jak i matka Yanagity były silnie związane z buddyzmem. Podobnie jego przyszła żona wywodząca się z rodu Yanagita.

8 Han - autonomiczna jednostka pod władzą księcia feudalnego daimyō. Hany zostały ustanowione w XVI w. przez Toyotomiego Hideyoshiego, zaś zniesiono je w 1871 r. i zastapiono prefekturami.

9 W latach 1638-1854 Japonia pozostawała w dobrowolnym zamknięciu na świat zachodni. Po burzliwym stuleciu chrześcijaństwa (1543-1638) religie chrześcijańskie były zakazane na terenie Wysp Japońskich, a jedynym oknem na Europe pozostawała mała holenderska faktoria handlowa na wyspie Dejima (u wrót portu w Nagasaki).

10 Bakumastu (jap. koniec rządów pod namiotem), okres przypadający na końcowe lata (18531867) ery Edo i rządów sioguna.

11 Ród Hirata słynął z łączenia myśli nacjonalistycznej z rodzimą religią shintō. 
W 1859 r. Misao osiedlił się w Tsujikawa, poślubił Take (1840-1896) i w latach 1863-1868 objął posadę nauczyciela w miejscowej szkole ufundowanej przez władze hanu Himeji ${ }^{12}$.

Czasy restauracji Meiji i przemian zachodzących w kraju okazały się wyjątkowo trudne dla rodziny Matsuoka. Misao wraz z utratą zatrudnienia w miejscowej szkole został zmuszony do przyjęcia posady głównego kapłana w świątyni Arata, jednocześnie pracując dorywczo w kilku szkołach. Sytuacja poprawiła się nieco wraz z podjęciem pracy nauczyciela w prefekturze Tottori, jednakże Misao nie podołał nowym obowiązkom i po 6 miesiącach zrezygnował z tej posady ${ }^{13}$. Przyczyn należy upatrywać w jego stylu życia, bowiem każdą wolną chwilę spędzał na układaniu poezji oraz poświęceniu się studiom nad doktrynami shintō. Owo oddanie nauce wzbudzało w rodzinie i wspólnocie szacunek dla Misao, a także gwarantowało rodowi Matsuoka utrzymanie specjalnego statusu we wsi, sytuując go ponad rodzinami rolniczymi, a w strefie wpływów i opieki potężnych możnowładców. Ród Miki cieszył się wyjątkowym poważaniem w okolicy. Wynajmował ziemię rodzinie Matsuoka, a także był właścicielem jednej z największych bibliotek w regionie. To właśnie z tego księgozbioru korzystał ojciec Kunio, gdy potrzebował tekstów i rzadkich książek do swoich studiów. „Yanagita był poniekąd krytyczny wobec ojca w odniesieniu do braku «praktycznej wiedzy», jednakże w pełni doceniał intelektualną stymulację z jego strony"14.

O matce Yanagity wiadomo stosunkowo niewiele. Pochodziła ze starego rodu zamieszkującego miasto Hōjō. Znana była ze swojego oddania rodzinie i pomocy mężowi. We wspomnieniach Kunio jawi się jako osoba opiekuńcza (w odniesieniu do potrzeb męża i dzieci, w szczególności małego Kunio), a przy tym znajdująca czas na pomoc innym. Yanagita wspomina, jak ciężko było matce zaadaptować się do zmieniających się warunków.

Właśnie owo przywiązanie do tradycji było główną przyczyną tragedii, jaka nawiedziła rodzinę Matsuoka. Yanagita wspomina w swojej pracy:

Mój najstarszy brat, Kanae, poślubił dziewczynę w wieku lat dwudziestu. Przybyła ona z sąsiedniej wsi. Jednakże nasz dom nie był wystarczająco duży, aby pomieścić dwie rodziny w tym samym momencie. Moja matka była silna i niewzruszona, jest oczywiste, że wspólne zamieszkiwanie dwóch rodzin wywoływało trudności. W tamtym czasie teściowa zawsze pokonywała synową w rodzinnych konfliktach, tak więc moja bratowa, nim upłynął rok, uciekła do swojego domu rodzinnego, a brat popadł w alkoholizm. Ponieważ ród Matsuoka miał silne tradycje medyczne, rodzice sprzedali część ziemi i dom, aby wysłać go do szkoły medycznej, która miała stanowić najszybszą ścieżkę edukacyjną do Tokijskiego Uniwersytetu Cesarskiego ${ }^{15}$. Tam miał możliwość studiowania medycyny bez

12 Szkoła została rozwiązana w 1868 r. wraz z wprowadzeniem nowego systemu szkolnictwa.

13 R.A. Morse, Yanagita Kunio..., s. 10.

14 Ibidem, s. 6.

15 Dzisiejszy Uniwersytet Tokijski. 
konieczności znajomości języka niemieckiego ${ }^{16}$. W wieku 26 lat ukończył szkołę, a że potrzebował pieniędzy na otwarcie własnej praktyki i wielu już było lekarzy w okolicy, nie miał zamiaru wracać w rodzinne strony. Zamiast tego ożenił się z kobietą ze starego rodu z prefektury Ibaraki i odziedziczył praktykę lekarską w mieście Fukawa.

Wrócił tylko raz po 30 latach do miasta rodzinnego - Tsujikawy. Po tylu latach utracił akcent charakterystyczny dla lokalnego dialektu. Kiedy wspominam tragiczny los mojego brata, chcę opowiedzieć innym, że dom, w którym się urodziłem, był najmniejszym domem w Japonii. Jest prawdopodobne, że moje zainteresowanie studiami nad folklorem japońskim związane jest z tą tragedią i najmniejszym domem w Japonii17.

Yanagita pozostał z rodzicami do 12. roku życia, kiedy to wraz z bratem przeprowadzili się do regionu Kantō. Młody Kunio zamieszkał u starszego brata - Kanae - w małym portowym mieście Fukawa zlokalizowanym nad rzeką Tone.

Kolejne lata spędzone we wschodniej Japonii uświadomiły Yanagicie różnice pomiędzy poszczególnymi regionami kraju. Dwie kwestie, na które szczególnie zwrócił uwage, były związane z honoryfikatywnością wypowiedzi oraz liczebnością rodziny. W zachodniej Japonii, której zdecydowanie bliżej było do tradycyjnych form komunikacji, formy grzecznościowe występowały w ogólnej komunikacji - nawet w grupie rówieśniczej, a ich brak zarezerwowany był jedynie dla najbliższej rodziny. W Fukawie młody Yanagita zetknął się z brakiem przyrostków honoryfikatywnych i tak z „Kunio-han/Kunio-yan” stał się z dnia na dzień po prostu „Kunio”. Drugą różnica, jaką zauważył, była relatywnie niewielka liczba dzieci w rodzinie. O ile w zachodniej Japonii normą było posiadanie szóstki lub więcej potomstwa, o tyle w prefekturze Ibaraki, do której trafił, przeciętna rodzina składała się z rodziców i (jedynie) dwójki dzieci ${ }^{18}$. Jakież zdziwienie wywoływała u rówieśników informacja o szóstce rodzeństwa młodego Yanagity. Należy mieć na uwadze, że region wschodniej Japonii nawiedzały często klęski nieurodzaju ${ }^{19}$ i klęski żywiołowe prowadzące do nawracających niedoborów żywności i głodu. Dlatego też ukształtował się system, w którym ograniczano liczbę dzieci w rodzinie, zarówno naturalnie, jak i przez praktykowane dzieciobójstwo. Po latach Yanagita zanotował:

16 W XIX w. uczelnie medyczne w Japonii były zasilane przez kadrę pochodząca z Prus. Dlatego też język niemiecki był, i jest do dzisiaj, istotnym elementem kształcenia studentów kierunków medycznych w Japonii.

17 Kunio Yanagita, Teibon Yanagita Kunio shü: Bekkan Dai 3, Tokyo 1971, s. 17.

$18 \mathrm{~W}$ tradycyjnych społecznościach rolniczych, do których należało japońskie społeczeństwo z czasów młodości Yanagity, posiadanie licznego potomstwa było gwarantem przetrwania rodu, gdyż dzieci stanowiły naturalną siłę roboczą w gospodarstwie. Dlatego też świadome ograniczenie liczebności potomstwa musiało wydawać się Yanagicie w początkowym okresie pobytu we wschodniej Japonii nienaturalne i nielogiczne.

19 Cieplejszy klimat południowo-zachodniej części Japonii umożliwia od dawna uzyskanie plonów dwa razy w roku. Dlatego też w perspektywie klęski nieurodzaju zawsze pozostawała szansa na udany kolejny zbiór. Dzięki temu w południowo-zachodniej części kraju zdecydowanie rzadziej praktykowano agresywną politykę kontroli liczebności populacji. 
Region ucierpiał w wyniku klęski głodu 40 lub 50 lat temu. Gdy ludzie cierpieli na niedobór pożywienia, jedynym rozwiązaniem była dla nich „śmierć”. Japonia utrzymywała swoją populację na poziomie $30 \mathrm{mln}$ do 1880 r., poprzez agresywną kontrolę narodzin, znacznie mniej przyzwoitymi metodami niż znane dzisiaj. Klęska głodu ery Tenmei zdewastowała regiony wzdłuż rzeki Tone i mimo że nie dysponujemy wieloma dokumentami dotyczącymi następnej klęski głodu, z ery Tenpō, wygląda na to, że ludzie ucierpieli w niej, zanim jeszcze podnieśli się z poprzedniej.

Moje wyraziste wspomnienie z życia nad rzeką Tone dotyczy małej świątyni Jizō, buddyjskiego bóstwa opiekuńczego dzieci. Tamże, na prawo od bóstwa znajdował się dar wotywny. Był to obraz przedstawiający kobietę, która właśnie zabiła swoje dziecko poprzez zaciskanie rąk na jego ciele. Jej cień na ścianie miał rogi na głowie. Jizō stojący obok płakał. Pamiętam, że zrozumiałem znaczenie tego obrazu i przeszedł mnie dreszcz ${ }^{20}$.

Możemy przyjąć, że owo doświadczenie głodu powiodło Yanagitę zarówno w kierunku badań folklorystycznych, jak i starań mających na celu rozwiązanie problemów z niedoborem pożywienia poprzez działalność w Ministerstwie Rolnictwa i Handlu. Yoneyama Toshinao uważa, że „Yanagita odkrył kulturę biedy w Kantō po przybyciu do Fukawy, a ze względu na widoczny kontrast z Banshū ${ }^{21}$ zaczął się interesować kulturowymi różnicami regionalnymi w Japonii"22.

\section{Literacki okres życia Yanagity}

Wspomniany na początku artykułu drugi brat Yanagity - Inoue Michiyasu ${ }^{23}$ - mieszkał w Tokio, gdzie uczęszczał do kolegium medycznego Tokijskiego Uniwersytetu Cesarskiego. Po kilku latach spędzonych w Fukawie Kunio został przeniesiony do Tokio, gdzie w latach 1892-1897 kształcił się w celu podjęcia nauki w Pierwszym Liceum w Tokio (w 1897 r.). Zmiana środowiska z wiejskiego na wielkomiejskie wywołała u Yanagity zainteresowanie twórczością literacką. Bliskość takich twórców, jak Kunikida Doppo (1871-1908), Tayama Katai (1871-1930) czy też Shimazaki Tōson (1872-1943) wpłynęła na szybki rozwój umiejętności poetyckich u młodego Kunio. Fascynacja ta przejawiała się u niego w komponowaniu zarówno utworów waka (krótkich utworów wierszowanych, poezji japońskiej), jak i poezji zachodniej. W efekcie licznych prób oraz konsultacji ukazał się tom zawierający utwory Yanagity i pięciu jego kolegów. Ponadto krótkie poematy publikowane były w magazynach literackich.

20 Kunio Yanagita, Teibon Yanagita Kunio shū..., s. 21.

21 Region Banshū odnosi się do miasta rodzinnego Yanagity.

22 Toshinao Yoneyama, Yanagita and his works [w:] International perspectives on Yanagita Kunio and Japanese Folklore Studies, eds. J.V. Koschmann, K. Ōiwa, S. Yamashita, New York 1985, s. 35.

${ }_{23}$ Podobnie jak Yanagita, również jego starszy brat został adoptowany i usynowiony, przyjmując nazwisko rodu żony. 
Warto dodać, że nawet podczas studiów w Katedrze Politologii na Wydziale Prawa Tokijskiego Uniwersytetu Cesarskiego Yanagita nie zaniechał twórczości literackiej. Dopiero kiedy zadebiutował w roli folklorysty (po ukazaniu się Tōno monogatari - Opowieści z. Tōno - w 1910 r.), zaczął powoli odcinać się od poetyckiej przeszłości ${ }^{24}$. Należy w tym miejscu zwrócić uwagę na fakt, że jego twórczość poetycka jest postrzegana jako romantyczna i pełna ekspresji. Ishida Eiichirō stwierdził, że naukowiec Yanagita nie mógł przezwyciężyć Yanagity poety i dlatego jego prace naukowe nigdy nie osiagnęły zakładanego celu ${ }^{25}$. Wtóruje temu stwierdzeniu Yoneyama Toshinao, który zauważył, że studia Yanagity nad kulturą japońską są niemożliwe do oddzielenia od jego spuścizny poetyckiej ${ }^{26}$. Bez watpienia doświadczenie wyniesione z obcowania z czołówką ówczesnej japońskiej elity literackiej oraz publikacja własnych utworów przyczyniły się do wnikliwej obserwacji i analizy folkloru, czego pierwszym przejawem była publikacja Tōno monogatari.

Warto również wspomnieć o tym, że po zakończeniu kariery politycznej w 1919 r. Yanagita został zatrudniony w „Asahi Shimbun”, jednym z czołowych japońskich dzienników, do którego w kolejnych latach napisał wiele artykułów i felietonów poświęconych swoim podróżom i odkryciom dotyczącym rodzimej kultury. Możemy ową współpracę traktować jako swoistą kontynuację kariery literackiej z czasów licealnych oraz studenckich.

\section{Adopcja i kariera urzędnicza}

Początek XX w. przyniósł w życiu młodego Yanagity (ówcześnie jeszcze Matsuoki) wiele zmian. W 1901 r. został adoptowany przez Yanagitę Naohei’a (1849-1930) ${ }^{27}$, przedstawiciela znanej i wpływowej rodziny z prefektury Nagano (dawniej Shinshū). Do dziś w Japonii praktykowana jest tradycja adopcji osób dorosłych, które w ocenie głowy rodziny jawią się jako perspektywiczni przyszli członkowie rodu. Stąd też możemy przyjąć, że młody Kunio, który ukończył prestiżowy wydział Tokijskiego Uniwersytetu Cesarskiego oraz był rozpoznawalny w środowisku literackim, wydawał się idealnym kandydatem na syna. W tym samym roku, już jako Yanagita, podją pracę w Ministerstwie Rolnictwa i Handlu. Co istotne, w 1904 r. poślubił czwarta córkę Naohei'a, $\mathrm{Ko}^{28}$, wiążąc się z rodem nie tylko jako adoptowany syn, ale przede wszystkim usynowiony zięć.

${ }^{24}$ Znanym faktem jest, że w Teihon Yanagita Kunio shü (Džiełach zebranych) nie zamieszczono ani jednego utworu poetyckiego Yanagity.

25 Eiichirō Ishida, Unfinished but enduring - Yanagita's Kunio Folklore Studies, „Japan Quarterly" 1963, vol. X, no. 1, s. 35-42.

26 Toshinao Yoneyama, Yanagita and his works...

27 W literaturze przedmiotu występuje również jako Yanagita Naohira.

28 W literaturze przedmiotu występuje również jako Yanagita Taka. 
Kariera w aparacie urzędniczym umożliwiła Yanagicie odbywanie licznych podróży po kraju. Początkowo był zainteresowany przede wszystkim poprawą bytu chłopów. Wskazywał na liczne nieprawidłowości w zarządzaniu gospodarstwami małorolnymi, takie jak sposób rozliczania podatku i czynszu w płodach rolnych, wynajem ziemi od właścicieli ziemskich czy też zastój w rolnictwie jako dziedzinie gospodarki. Jego świeże spojrzenie oraz charyzma sprawiły, że był zapraszany do wielu najodleglejszych zakątków kraju. Jego wykłady i odczyty były publikowane w czasopismach rolniczych i przysparzały mu zarówno zwolenników, jak i przeciwników. Ci ostatni nawoływali do zachowania status quo. Analiza znaczenia propozycji reform znacznie wykracza poza zakres niniejszego opracowania, dość jednak wspomnieć, że po 1945 r. reformy japońskiego rolnictwa zostały przeprowadzone na wzór zaproponowany przez Yanagitę ${ }^{29}$.

Dzięki licznym podróżom służbowym Yanagita miał możliwość odkrywania japońskiego folkloru. Tutaj nasuwa się pytanie o przyczyny tak częstych wyjazdów. $Z$ jednej strony można przyjać, że Yanagita przyciagał uwagę jako młody reformator nawołujący do wprowadzenia zmian w japońskim rolnictwie, z drugiej zaś wielu biografów wskazuje na trudny związek małżeński z Kō (oraz relacje z rodziną Yanagita) jako przyczynę ucieczek Kunia w interior ${ }^{30}$.

Praca w administracji centralnej pochłaniała Yanagite przez 18 lat (do 1919 r.). W tym czasie, będąc zdolnym urzędnikiem, awansował z zajmowanego etatu administracyjnego w Ministerstwie Rolnictwa i Handlu na stanowisko sekretarza generalnego Izby Wyższej Parlamentu (jap. Kizoku-in, ang. House of Peers). Wspomniane już wizytacje w różnych regionach kraju oraz możliwość dostępu do zbiorów biblioteki parlamentarnej zarezerwowanej jedynie dla elit rządzących kształtowały myśl naukową Yanagity. Zarówno przestudiowane w bibliotece księgi oraz dokumenty, jak i liczne wyjazdy były dla niego pretekstem do obserwowania różnorodności kulturowej Japonii.

\section{W stronę folklorystyki japońskiej}

Końcówka pierwszej dekady XX w. przyniosła zmianę zainteresowań Yanagity. Badacz pod wpływem licznych podróży zaczął dostrzegać, że nie istnieje jeden sprawdzony i wspólny sposób analizowania społeczeństwa japońskiego. Proponowane w pierwszych latach działalności urzędniczej reformy japońskiego rolnictwa były planowane z punktu widzenia centrum kraju, czyli Tokio. Yanagita, odwiedzając liczne regiony peryferialne, dostrzegł ich bogate zróżnicowanie kulturowe. Był prze-

\footnotetext{
29 Dokładną analizę można znaleźć w pracy: Minoru Kawada, The Origin of Ethnography in Japan. Yanagita Kunio and his Times, London - New York 1993, s. 81-107.

30 Zob. Azio Fukuta, Yanagita Kunio no minzokugaku, Tokyo 2007.
} 
konany o tym, że w odległych od stolicy miejscach zachowały się formy kulturowe z przeszłości. Swoje przemyślenia wspierał licznymi przykładami zaczerpniętymi z kronik oraz literatury powstałej w okresie Edo (1603-1868). Pierwszą próbę analizy zróżnicowania kulturowego Japonii zawarł w pracy Nochino karikotoba no ki (Dodatkowe zapiski o terminologii łowieckiej) z 1909 r. ${ }^{31}$ W książce wydanej za własne pieniądze Yanagita opisał najważniejsze terminy z zakresu łowiectwa używane przez myśliwych z prefektury Miyazaki (ze wsi Shiiba). Warto tu nadmienić, że metody łowieckie stosowane we wsi Shiiba były niezmienne od wielu pokoleń i specjalnie dla badacza udostępniono głęboko skrywane sekrety. Owo odkrycie dla ówczesnego nowoczesnego świata przeszłości stanowiło według Yanagity dowód na funkcjonowanie różnych typów kultury japońskiej ${ }^{32}$.

Drugim przełomowym momentem w naukowym życiu Yanagity było spotkanie z Sasaki Kizenem (1886-1933) ${ }^{33}$. Na przełomie 1908 i 1909 r. z Tōno do Tokio przybył młody pasjonat lokalnej kultury - Sasaki Kizen. Poszukiwał kogoś, kto pomoże mu upowszechnić lokalne wierzenia. W tym czasie Yanagita, nadal udzielający się w kręgach literackich, prowadził seminaria poświęcone kulturowemu zróżnicowaniu kraju oraz możliwym metodom badawczym. Sasaki został skierowany do domu Yanagity, gdzie przez dłuższy czas zaznajamiał go z lokalnymi wierzeniami, podaniami oraz realiami. Następnie Kunio przygotował pierwotną wersję tekstu, jednakże przed jego publikacją zdecydował się odwiedzić Tōno, aby na własne oczy zobaczyć miejsce, o którym z wielką pasją opowiadał Sasaki. We wstępie do Tōno monogatari zanotował:

Wszystkie te zapisane opowieści zostały mi opowiedziane przez Sasakiego (Kyoseki) Kizena, który zamieszkuje Tōno. Zapisałem je w taki sposób, jak mi je podano podczas wielu wieczornych wizyt w lutym 1909 r. Kizen nie ma daru opowiadania, ale jest szczery i dobroduszny. Zapisałem je tak, jak je zrozumiałem, nie dodając ani słowa, ani

31 Kunio Yanagita, Yanagita Kunio zenshu, t. 5, Tokyo 1989, s. 7-54.

32 Wielokulturowość Japonii według Yanagity przejawiała się w funkcjonowaniu w tym samym czasie kilku różnych form kulturowych charakterystycznych dla różnych okresów historycznych. Yanagita rozróżniał Japończyków współczesnych, którzy wywodzili się od ludności okresu Yayoi (X w. p.n.e. $-I V$ w. p.n.e. - wczesny okres Yayoi, IV/III w. p.n.e.-III w. n.e. - właściwy okres Yayoi) oraz wcześniejszych mieszkańców wysp - ludność Jōmon (14 000-1000 r. p.n.e.) - zepchniętych przez migrantów Yayoi do odległych, niekorzystnych regionów kraju (góry, zimna północ itd.). To właśnie prowadziło do izolacji niektórych społeczności i zachowania pierwotnych form kulturowych. W tym aspekcie przemyślenia Yanagity pokrywają się z popularną w zachodniej antropologii koncepcją ewolucjonizmu kulturowego - ewolucji jednoliniowej, w myśl której, analizując ludy zapóźnione w rozwoju (społeczno-kulturowym), można opisać przeszłość ludów rozwiniętych.

33 Sasaki Kizen był japońskim folklorystą urodzonym i żyjącym w Tōno, w prefekturze Iwate na północy kraju. Często zwany jest japońskim Grimmem, gdyż zbierał i upowszechniał legendy, które krążyły w regionie. 
frazy. Wyobrażam sobie, że jest wiele więcej takich legend, jak te tu zamieszczone, i mam nadzieję, że one również zostaną usłyszane w przyszłości. W górskich wsiach Japonii, w regionach dalszych niż Tōno, musi być nieskończona liczba innych podań o ludziach i duchach zamieszkujących góry ${ }^{34}$.

Pierwsze wydanie Tōno monogatari ukazało się w 1910 r. Yanagita, ponownie wykorzystując własne środki finansowe, opublikował pracę o charakterze folklorystycznym. Pierwotnie niewielki nakład był przeznaczony jedynie dla przyjaciół badacza. Jednakże sukces, jaki odniosła książka, spowodował, że marka Yanagity jako folklorysty i znawcy kultury japońskiej została na trwałe zapisana w japońskiej nauce ${ }^{35}$. Książka zawierająca 119 spisanych legend stała się swoistym znakiem rozpoznawczym zarówno Yanagity, jak i okresu w dziejach literatury japońskiej. Yoneyama Toshinao, wtórując Kawabarze Takeo, zauważa, że „Opowieści z Tōno sa jednym z najważniejszych literackich wytworów epoki. Niektórzy z literackich przyjaciół Yanagity określali się mianem «naturalistów», jednakże Yanagita opuścił tę szkołę i zaczął pisać swoim własnym stylem. Jego styl jest jasny, elegancki, narracyjny, z pobrzmiewającym echem epoki Edo"36.

Ostatnią kwestią związaną z Tōno monogatari jest dedykacja zamieszczona na początku pracy, która brzmi: Kono sho wo gaikoku ni aru bitobito ni teisu ${ }^{37}$ (Dla moich przyjaciół za granica/Dla ludzi będących za granica). Owa dedykacja jest swoistym symbolem epoki Meiji (1868-1912). Warto mieć w pamięci, że czasy restauracji Meiji to okres wielkiej transformacji społeczeństwa japońskiego. Japonia po ponad 200 latach otworzyła swoje granice dla ludzi z Zachodu, jednocześnie dopuszczając swoich obywateli do wyjazdów zagranicznych. Jak zauważa Yoneyama Toshinao: „Pod koniec okresu Meiji Japonia była praktycznie innym krajem niż na jego początku. Dlatego termin «za granicą» może być interpretowany w tym znaczeniu. Dla mnie najważniejszym osiągnięciem tej książki jest jej zdolność do utrwalenia tradycji ustnej prawie zapomnianej wraz z upływem czasu”38. Yoneyama utożsamia „pprzyjaciół za granicą" z zanikającymi w mrokach przeszłości japońskimi tradycjami i to im ma Yanagita dedykować swoją pracę ${ }^{39}$.

${ }^{34}$ Kunio Yanagita, The legends of Tono. $100^{\text {th }}$ Year Anniversary edition, trans. R.A. Morse, Lanham Bouldler - New York 2008, s. 5.

35 Warto zwrócić uwagę na fakt, że Sasaki Kizen wydał w latach 30. XX w. własną wersję Opowieści z Tōno. Współcześnie uznaje się, że obie wersje stanowią oddzielne formy. Praca Yanagity postrzegana jest jako wersja literacka, podczas gdy opracowanie Sasakiego stanowi przykład opowieści w stylu naturalnym, pierwotnym, zasłyszanym od autochtona.

36 Toshinao Yoneyama, Yanagita and his works..., s. 38.

37 Kunio Yanagita, Yanagita Kunio zenshü, t. 4, Tokyo 1989, s. 8.

38 Toshinao Yoneyama, Yanagita and his works..., s. 39.

39 Być może wytłumaczenie dedykacji jest znacznie bardziej prozaiczne, gdyż gros przyjaciół Yanagity przebywało poza granicami Japonii w momencie pierwszej publikacji Tōno monogatari; zob. Kunio Yanagita, The legends of Tono..., s. 3. 


\section{Japończycy w twórczości Yanagity}

Od początku swoich zainteresowań folklorem japońskim i wynikającym z niego zróżnicowaniem regionalnym Yanagita próbował odpowiedzieć na pytanie, które grupy powinny być przedmiotem zainteresowania nowo powstającej nauki. Doświadczenie wyniesione ze studiów w bibliotekach uniwersyteckich i parlamentarnych oraz przynależność do wyższej warstwy społecznej uświadomiły badaczowi, że wiedza zawarta w źródłach pisanych jest niepełna i stronnicza. W myśl zasady, że „historię piszą zwycięzcy”, Yanagita zaczął zastanawiać się nad lokalną wizją wydarzeń z przeszłości oraz rolą, jaką w nich odegrali zwykli ludzie. W opublikowanych w latach 20. i 30. XX w. pracach Yanagita starał się wskazać na cechy odróżniające „zwykłych ludzi” od rządzących. Służył temu utworzony przez niego termin jōmin (stały zwykły człowiek) ${ }^{40}$, funkcjonujący w opozycji do określeń zmieniającej się władzy, która pozostawiała po sobie teksty pisane.

Najbardziej znane analizy pochodzą z dwóch prac: Toshi to nōson ${ }^{41}$ (Miasto i wies) oraz Meiji Taishō shi: sesō hen ${ }^{42}$ (Historia Meïi i Taishō: Sprawy spoteczne). Od początku swojej działalności na polu folklorystyki Yanagita koncentrował się na zwykłych ludziach jako najważniejszym nośniku tradycyjnej kultury. Wychodził z założenia, że elity kraju, które pozostają pod wpływem zewnętrznych prądów kulturowych, nie mają tak silnego związku z przeszłością jak mieszkańcy mocno oddalonej od centrów kulturowych prowincji. Ślady jego poszukiwań odnajdujemy we wspomnianych już wcześniej Nochino karikotoba no ki oraz w Tōno monogatari. Termin jōmin nie był stały. Początkowo Yanagita stosował go zamiennie z heimin i shomin, które mają podobne znaczenie. Z biegiem czasu, w okresie formowania natywnej japońskiej folklorystyki, ugruntował jōmin jako jeden z podstawowych terminów swojej nauki, jednocześnie rezygnując ze stosowania pozostałych dwóch. Co więcej, również zakres tego pojęcia zmieniał się. W początkowych latach działalności naukowej (lata 20. XX w.) Yanagita używał tego terminu w odniesieniu do społeczności wiejskich zamieszkujących odległe górskie wsie. Natomiast na przełomie lat 30. i 40. XX w. Yanagita jako jōmin określał wszystkich mieszkańców Japonii (w tym również cesarza) ${ }^{43}$. Warto zauważyć, że pierwotne społeczne znaczenie terminu (jömin jako forma grupy produkcyjnej) zanikło w drugiej połowie lat. 30. ubiegłego stulecia. Należy łączyć to

\footnotetext{
40 Szczegółowo na temat jōmin zob. J. Splisgart, Od historii pisanej do historii mónionej: wplyw myśli Yanagity Kunio na rozwój nank etnologicznych w Japonii [w:] Historia, interpretacja, reprezentacja, red. M. Żmudzka-Brodnicka, M. Brodnicki, J. Serkowska-Mąka, Gdańsk 2012, s. 115-123.

41 Książka pierwotnie opublikowana w 1929 r., obecnie dostępna w: Kunio Yanagita, Yanagita Kunio zenshu, t. 29, Tokyo 1991, s. 333-541.

42 Pierwotnie opublikowanej w 1931 r., obecnie dostępnej w Kunio Yanagita, Yanagita Kunio zenshu, t. 26, Tokyo 1990, s. 7-394.

43 Cesarz Japonii traktowany był jako pierwszy i najważniejszy spośród jōmin.
} 
z wyraźnie prawicowym zwrotem w polityce kraju, który piętnował i tępił wszelkie przejawy lewicowej ideologii ${ }^{44}$.

\section{Powrót do domu - przywrócenie Okinawy do macierzy}

Na koniec warto wspomnieć o jeszcze jednym ważnym osiagnięciu Yanagity. W latach 30. XX w. zrodziła się w Japonii nowa nauka - folklorystyka Yanagity. Badacz po ponad trzech dekadach prowadzenia badań, licznych wyjazdach - krajowych i zagranicznych - zdecydował się na pełną konceptualizację swojego projektu. Miał rozległa sieć informatorów (lokalnych badaczy) oraz grupę zaufanych uczniów, którzy byli przez niego przeszkoleni zarówno od strony teoretycznej, jak i praktycznej ${ }^{45}$. Długi pobyt w Europie w pierwszej połowie lat 20. XX w. zaowocował nawiazaniem licznych kontaktów z zachodnimi antropologami społeczno-kulturowymi, folklorystami oraz przedstawicielami innych dyscyplin naukowych ${ }^{46}$. Ponadto Yanagita pozyskał wiele opracowań naukowych zawierających omówienia najnowszych ówcześnie teorii w zakresie badania kultury.

Połączenie doświadczenia europejskiego z japońskimi warunkami zaowocowało w 1935 r. oficjalnym debiutem folklorystyki japońskiej (Yanagita minzokugaku). Data nie jest przypadkowa. W 1935 r. Yanagita ukończył 60 lat i z tej okazji zorganizowano w Tokio sympozjum, podczas którego przedstawiono założenia metodyczne folklory-

44 Folklorystyka Yanagity pozostawała neutralna światopoglądowo i stanowiła swoiste schronienie dla licznych lewicowych myślicieli okresu międzywojennego oraz czasu wojny. Poprzez zmianę zakresu znaczeniowego terminu jömin Yanagita chronił zarówno swoją naukę, jak i jej adeptów, odsuwając od siebie podejrzenia o lewicowy charakter przemyśleń.

$45 \mathrm{~W}$ założeniu Yanagity podstawę przy zbieraniu materiałów badawczych stanowili lokalni pasjonaci, którzy, mając nieskrępowany dostęp do miejscowego społeczeństwa, mieli jednocześnie możliwość łatwego pozyskania danych. Sieć informatorów obejmowała cały kraj. Każdy z nich przesyłał do Tokio materiały, które następnie były analizowane i selekcjonowane przez uczniów Yanagity. Ostatni etap stanowiło przygotowanie całości do druku, czym zajmował się sam Yanagita. Proces budowy sieci informatorów oraz pozyskania materiałów badawczych został szczegółowo omówiony w pracy Alana Christy pt. Discipline on foot. Inventing Japanese Native Ethnography 1910-1945, Lanham - Bouldler - New York 2012.

46 Yanagita przebywał w Europie w latach 1921-1923 (z przerwa pomiędzy grudniem 1921 a majem 1922 r.) jako japoński przedstawiciel w Lidze Narodów. Uczestnicząc podczas pierwszego pobytu (maj-grudzień 1921) w pracach komisji zajmującej się kwestiami geopolityki na Pacyfiku, zwracał szczególną uwagę na rolę rasy w dyskursie politycznym panującym na Zachodzie (jak np. szeroko dyskutowana kwestia żółtego zagrożenia w USA). Ponadto poprzez obserwacje Japończyków dostrzegł istotę zachowań kolektywnych w swoim kraju. Nabrał również szacunku dla europejskich zdobyczy kulturowo-społecznych. Drugi pobyt upłynął Yanagicie na zwiedzaniu bibliotek, uniwersytetów oraz na spotkaniach z europejskimi uczonymi. Powrócił do Japonii w listopadzie 1923 r. po otrzymaniu wiadomości o Wielkim Trzęsieniu Ziemi w Kantō (1 września 1923 r.). 
styki. Jako podstawę do analizy wykorzystywano dostosowaną do lokalnych warunków teorię kręgu kulturowego, w myśl której zmiany zachodzą w centrach kulturowych, a następnie nowe elementy rozchodzą się cylindrycznie w kierunku peryferiów kulturowych $^{47}$. W ujęciu Yanagity najstarsze formy kulturowe znajdowały się na obrzeżach japońskiej etnosfery i właśnie tam należało poszukiwać korzeni japońskiej kultury. Badacz był przekonany, że pierwotne centrum kulturowe Wysp Japońskich znajdowało się w regionie Kinki (obejmującym takie ośrodki miejskie, jak Kioto - pierwotnie Heiankyō, Osaka - pierwotnie Naniwa czy też Nara - pierwotnie Heijōkyō) i to stamtąd rozchodziły się wszelkie innowacje społeczno-kulturowe ${ }^{48}$. W myśl przyjętych założeń najstarszych (początkowych) form kulturowych należało poszukiwać poza granicami głównych wysp ${ }^{49}$, w regionach Hokkaido i na archipelagu Riukiu.

Swoje przemyślenia zawarł w dwóch książkach: Kainan shōki (Nota o morzach południowych) ${ }^{50}$ z 1925 r. oraz w Kaijō no michi (Droga przez. morza) ${ }^{51}$ z 1961 r. Pierwsza ze wspomnianych prac jest zapisem przemyśleń z podróży Yanagity z Kiusiu na Okinawę w latach 20. XX w. Zauważył, że wiele spośród niewystępujących już na głównych wyspach zwyczajów nadal jest pielęgnowanych na archipelagu Riukiu. Co więcej, obserwując fale odbijające się od brzegu, które przynosiły ze sobą orzechy kokosowe, wysnuł teorię o południowym pochodzeniu przodków współczesnych Japończyków. Teoria nie była rozwijana do lat 50. XX w. ze względu na niesprzyjające warunki polityczne. Dopiero pod koniec życia, po II wojnie światowej i zakończonej okupacji amerykańskiej, Yanagita powrócił do swoich przemyśleń na temat pochodzenia mieszkańców Wysp Japońskich w pracy Kaijō no michi. Ostatnie dzieło zostało opublikowane w czasach, gdy Okinawa znajdowała się pod jurysdykcją amerykańska. Yanagita starał się wskazać na elementy z jednej strony potwierdzające południowe pochodzenie Japończyków, z drugiej zaś łączące Okinawę z Japonią. W teorii Yanagity szczególną uwagę przyciaga znaczenie muszli, które według niego służyły jako cenny środek wymiany towarowej, ale poza Okinawą nie występowały na terenie innych wysp mórz południowych ${ }^{52}$. To właśnie poszukiwania tego cennego towaru miały przyciągnąć ludność z południa najpierw

\footnotetext{
47 Więcej na temat metodologii badawczej japońskiej folklorystyki zob. Minoru Kawada, The Origin of Ethnography in Japan..., s. 108-140.

48 Przykładem może być buddyzm, który rozwijał się w Japonii od VI w. n.e. Początkowo główne centrum nowych wierzeń znajdowało się w regionie Kinki, a w okresie Nara (710_ 794 r. n.e.) stolica kraju stanowiła wręcz stolicę całego buddyjskiego świata.

49 Za główne wyspy uznawano w latach 30. XX w. Honsiu, Sikoku i Kiusiu. Hokkaido (dawniej Ezo) do XIX w. pozostawało poza zainteresowaniami Japończyków, zaś królestwo Riukiu zawsze znajdowało się na styku dwóch sfer kulturowych - japońskiej i chińskiej. Oba te regiony zamieszkiwały ludy, których nie uznawano za rodowitych Japończyków.

50 Kunio Yanagita, Yanagita Kunio ženshu, t. 1, Tokyo 1989, s. 297-523.

51 Ibidem, s. 7-296.

52 Morza południowe w ujęciu badacza to Morze Wschodniochińskie oraz Morze Filipińskie.
} 
na teren archipelagu Riukiu, a następnie na Kiusiu, skąd rozpoczęła się migracja ku północy. Teza Yanagity odegrała istotną rolę w staraniach o odzyskanie Okinawy i w jej kulturowym „powrocie” do macierzy. Jednakże współcześnie możemy uznać, że założenia przyjęte przez badacza były zbyt daleko idące, a sam Yanagita nie dostrzegał związku Japończyków i ich kultury z kontynentem, w szczególności z Korea, bądź ignorował go ${ }^{53}$.

\section{Podsumowanie}

Niezależnie od współczesnej oceny prac napisanych przez Yanagitę jego dorobek na polu tworzenia i rozwoju studiów folklorystycznych w Japonii pozostaje niezaprzeczalny. Udało mu się dokonać zapisu zanikającej tradycji ustnej w regionach usytuowanych daleko od głównych centrów kulturowych kraju. Jako pierwszy z japońskich naukowców wskazał na znaczenie folkloru w badaniach nad przeszłością oraz zakwestionował bezstronność i nieomylność źródeł historycznych. Istotnym wkładem w rozwój japońskiej folklorystyki jest również przygotowanie założeń metodologicznych dla prowadzonych badań terenowych. Yanagita rozróżnił trzy podstawowe stadia pozyskania danych. Pierwszym była obserwacja, drugim rozmowa, zaś trzecim zrozumienie (przemyślenie) całości. Zaznaczał przy tym, że pierwszy etap zarezerwowany jest dla przelotnych turystów, drugi cechuje długoterminowych rezydentów, zaś trzeci dotyczy ludzi na stałe zamieszkujących badany region. Jego podejście do badań terenowych było unikatowe dla japońskiej nauki, która koncentruje się na badaniach gabinetowych (w laboratoriach i bibliotekach). W tym ujęciu możemy uznać, że Yanagita Kunio nie tylko stworzył natywną folklorystykę, ale był również pionierem japońskiej antropologii społeczno-kulturowej. Do dziś wszyscy studenci kierunków antropologicznych w Japonii rozpoczynają swoje studia badawcze od problematyki rodzimej folklorystyki, a dopiero po jej zgłębieniu zajmują się zaawansowanymi kwestiami kultur pozawyspiarkich.

\section{SUMMARY}

\section{YANAGITA KUNIO (1875-1962). PIONEER OF JAPANESE FOLKLORE STUDIES}

The Meiji era (1868-1912) pushed Japan towards a modern, industrialized and, most of all, positivist state. This era plays an important role in shaping the ethnographic (anthropological, folklore) thought in the country. However, this is only one side of the coin, a medal

\footnotetext{
53 Więcej na ten temat zob. Toshinao Yoneyama, Yanagita and his works..., s. 51-52.
} 
which, apart from a gigantic leap in civilization, had a reverse - traditional, familiar, "Japanese" side. Japan went through two important periods of modernization in the years of 1868-1962. From a feudal country ruled by samurai transformed into a country capable of competing with the previously industrially developed colonial powers, and after World War II, giving up imperial ambitions, transformed into a modern state. During the century, numerous changes have occurred in the streets of the Japanese capital. From the carriages, trough automobiles, and finally, after 1945, to the jets flying overhead. It was in such times that the pioneer of Japanese ethnography, folklore or socio-cultural anthropology, Yanagita Kunio, came to live and work. This text aims to present the profile and main theses of this Japanese researcher. 